\title{
Effect of 2-Propanol on the Transfer Hydrogenation of Aldehydes by Aqueous Sodium Formate using a Rhodium(I)- sulfonated Triphenylphosphine Catalyst
}

\author{
Ágnes Kathóª, Imre Szatmária, Gábor Papp ${ }^{b}$, and Ferenc Joóab
}

\begin{abstract}
In water/2-propanol mixtures $\left[\mathrm{RhCl}(m \mathrm{tppms})_{3}\right]$ ( $m$ tppms $=$ monosulfonated triphenylphosphine) was an efficient catalyst for the selective $\mathrm{C}=\mathrm{C}$ reduction of trans-3-phenyl-2-propenal (trans-cinnamaldehyde) by hydrogen transfer from formate at temperatures as low as $30^{\circ} \mathrm{C}$. An outstandingly high catalyst turnover frequency of $1214 \mathrm{~h}^{-1}$ was determined at $70^{\circ} \mathrm{C}$. A possible mechanism of the reaction is suggested on the basis of kinetic studies and ${ }^{1} \mathrm{H}$ - and ${ }^{31} \mathrm{P}$-NMR spectroscopic identification of the major $\mathrm{Rh}(1)$ species in the reaction mixtures as cis-mer- $\left[\mathrm{H}_{2} \mathrm{RhX}(m \mathrm{tppms})_{3}\right]\left(\mathrm{X}=\mathrm{HCOO}^{-}\right.$or $\left.\mathrm{H}_{2} \mathrm{O}\right)$. It was established that a large part but not all of the rate increase observed in water/2-propanol mixtures in comparison with systems with neat water as solvent was the consequence of complete dissolution of trans-cinnamaldehyde on the effect of the co-solvent. Nevertheless, the rate showed a significant further increase with increasing 2-propanol concentration even in homogeneous solution and this was ascribed to changes in the solvent structure. The high catalyst activity in this solvent mixture allowed the transfer hydrogenation of citral. Although good to excellent conversions were observed at $30-70^{\circ} \mathrm{C}$, a useful degree of selectivity in hydrogenation of $\mathrm{C}=\mathrm{C}$ vs. $\mathrm{C}=\mathrm{O}$ bonds could not be achieved.
\end{abstract}

Keywords: Aldehydes · Rhodium-phosphine catalyst · Sodium formate · Transfer hydrogenation · Water

\section{Introduction}

Homogeneous catalysis allows precise control of the composition and structure of molecularly dispersed catalysts resulting in their efficient use and in their ability to effectively govern selectivities of the catalysed reactions. Of the many examples, one may refer to the asymmetric hydrogenation of various prochiral substrates ${ }^{[1]}$ or to the stereocontrolled olefin metathesis reactions. ${ }^{[2]}$ Platinum group metal complexes feature frequently as catalysts for such reactions, often containing expensive ligands, so that recovery of such catalysts

\footnotetext{
${ }^{\star}$ Correspondence: Dr. Á. Kathóa Tel.: +36 52512 900, ext. 22383 E-mail: katho.agnes@science.unideb.hu aDepartment of Physical Chemistry University of Debrecen H-4010 Debrecen, P.O. Box 7, Hungary 'MTA-DE Homogeneous Catalysis and Reaction Mechanisms Research Group
} H-4010 Debrecen, P.O.Box 7, Hungary is a prerequisite for their practical application. This can be achieved relatively simply by using liquid biphasic reaction systems. In such reactions, the catalyst is dissolved in one of the liquid phases which is immiscible (slightly miscible) with the other liquid phase containing the substrate and the product. ${ }^{[1,3]}$ In the most favourable cases, product isolation and catalyst recovery requires simple phase separation. Water is a most suitable solvent for such biphasic reactions, ${ }^{[4]}$ since it does not mix with many of the commonly used organic solvents. In addition, water is a natural solvent choice for reactions of substrates which dissolve preferably (or exclusively) in water or for reactions in which water is one of the reactants (such as hydration ${ }^{[5]}$ of alkynes, nitriles, etc.). Consequently, it is a common situation in aqueous organometallic catalysis that the catalysts operate in an aqueous solution (phase) in contact with organic solvents.

In comparison to the widely used organic solvents, water is not simply an alternative dissolving agent but has its own requirements and effects, too. First of all, in aqueous-organic biphasic systems strongly hydrophilic catalysts are needed in order to maintain the catalyst exclusively in the aqueous phase. There are many hydrophilic ligands suitable for synthesis of water-soluble transition metal complex catalysts. ${ }^{[4]}$ The most widely investigat- ed ligands are the monosulfonated and trisulfonated triphenylphosphines ( $m$ tppms = sodium 3-diphenylphosphinobenzenesulfonate ${ }^{[6]}$ and $m$ tppts $=$ trisodium 3,3',3"'-phosphinetriylbenzensulfonate, [7] respectively) as well as 1,3,5-triaza-7phosphaadamantane $(\mathrm{pta}=1,3,5$-triaza7-phosphatricyclo[3.3.1.1] decane). [8] Recently, water-soluble $\mathrm{N}$-heterocyclic carbene ligands and complexes have also received increasing attention. ${ }^{[5 a b, 9]}$ The presence of water in the solvent may considerably influence the rates and selectivities of reactions performed in aqueous systems. For example, the $\left[\mathrm{RhCl}(m \mathrm{tppms})_{3}\right]-$ catalysed hydrogenation of fumaric acid proceeded much faster in water ${ }^{[10]}$ than in water-diglyme mixtures or in pure diglyme. In contrast, the highest rate of hydrogenation of maleic acid was observed in diglyme as solvent, and it decreased with increasing percentage of water in diglymewater mixtures.[10c] Another interesting example is the hydrogenation of 2,6-hexadienoic (sorbic) acid. Hydrogenation of potassium sorbate in water with a $\left[\mathrm{RhCl}(m \text { tppms })_{3}\right]$ catalyst was comparable to hydrogenation of sorbic acid in ethyl acetate with $\left[\mathrm{RhCl}\left(\mathrm{PPh}_{3}\right)_{3}\right]$ concerning both the rates and the selectivities of the reactions. However, in a water-ethyl acetate biphasic system and with [RhCl( $m$ tppms $\left.)_{3}\right]$ as catalyst, hydrogenation of sorbic acid proceeded faster and more selectively than 
in any of the homogeneous solutions. ${ }^{[11]}$ There are examples of aqueous-organic biphasic reactions where the presence of water (often as a separate aqueous phase) has large effects even on reactions taking place in organic solution with an organosoluble catalyst, such as the case of transfer hydrogenation of ketones from formate with half-sandwich $\mathrm{Ru}(\mathrm{II})$-diamine catalysts in which Xiao et al. have found large rate increases relative to the pure organic solvents. ${ }^{[12]}$ By a multilateral mechanistic study it was revealed that water directly participated in the hydrogen transfer process. ${ }^{[12 c]}$

Selective hydrogenation of unsaturated aldehydes either to unsaturated alcohols or to saturated aldehydes is a synthetically most useful reaction. This transformation can be achieved by catalytic hydrogenation with $\mathrm{H}_{2}$ or by catalytic hydrogen transfer from certain H-donors, of which 2-propanol and formic acid or formate salts are the most prominent. A specific way of transfer hydrogenation applies aqueous solutions of formate salts (most often HCOONa) and Rh(I)- or Ru(II)tertiary phosphine complex catalysts. Although water-insoluble catalysts (such as $\left.\left[\mathrm{RuCl}_{2}\left(\mathrm{PPh}_{3}\right)_{3}\right]\right)$ can also be used (and in that case they are dissolved in the aldehyde-containing organic phase in contact with an aqueous HCOONa solution), [13] a more practical approach is to use water-soluble catalysts dissolved in the aqueous formate phase. ${ }^{[14]}$ Several studies have revealed that in aqueous biphasic reactions of unsaturated aldehydes $\left[\mathrm{RhClP}_{3}\right]$-type complexes selectively hydrogenated the carbon-carbon double bond, ${ }^{[15]}$ while the $\left[\mathrm{RuCl}_{2}\left(\mathrm{PR}_{3}\right)_{3 \text { or } 4}\right]$ catalysts showed $\mathrm{pH}$-dependent selectivity: in acidic solutions a slow hydrogenation of the $\mathrm{C}=\mathrm{C}$ bond was observed, while in basic solutions the aldehyde function was rapidly hydrogenated. ${ }^{[16]}$ Accordingly, in biphasic transfer hydrogenations from aqueous $\mathrm{HCOONa}$ (slightly basic aqueous phase) selective reduction of unsaturated aldehydes to unsaturated alcohols could be achieved.[17]

Addition of alcohols to aqueous reaction mixtures of hydrogenation, transfer-hydrogenation, hydroformylation, etc. has often been found advantageous. For example, hydrogenation of trans-cinnamaldehyde (trans-3-phenyl-2-propenal) was accelerated by ethylene glycol; in fact, the reaction showed the highest rate in pure ethylene glycol in which the $\mathrm{Rh}(\mathrm{I})$-based catalysts, such as Rh(I)-(L)cysteine, were soluble. ${ }^{[18]}$ Ajjou and Pinet studied transfer hydrogenation of various aldehydes and ketones in mixtures of water and 2-propanol with a catalyst prepared in situ from $\left[\{\mathrm{RhCl}(\mathrm{COD})\}_{2}\right]+15 \mathrm{mtppts}$ ( $\mathrm{COD}=1,5$-cyclooctadiene $)$ in the presence of $\mathrm{Na}_{2} \mathrm{CO}_{3}$ as base and found high conversions at $80^{\circ} \mathrm{C}$ in 2 h. ${ }^{[19]}$ Under the reaction conditions the mixtures were homogeneous, and 2-propanol had a dual role as solvent and $\mathrm{H}$-donor.

Organic co-solvents may have various effects on the kinetics of a reaction catalysed by organometallic complexes in partially aqueous solutions. They may increase the solubility of gaseous reactants $\left(\mathrm{H}_{2}, \mathrm{CO}\right.$, etc. $)$ and that of slightly soluble substrates (alkenes, alkynes, etc.). In biphasic systems co-solvents may facilitate the phase transfer of the substrate to the catalyst-containing aqueous phase and the transfer of the product from the aqueous to the organic phase. Many of the organic substrates have such low solubility in water that their reactions in aqueous-organic biphasic systems are impracticably slow. Addition of co-solvents often leads to formation of homogeneous reaction mixtures characterized by higher reaction rates than their biphasic counterparts, however, isolation of the product and recovery of the catalyst in these cases are no longer possible by simple phase separation. At the end of the reaction, phase separation can be induced by proper manipulation of the solvent composition (e.g. by increasing the amount of one of the solvents in the mixture, or by addition of a third solvent) and although at first this may not seem economical, smart engineering solutions can allow incorporation of induced phase separation even into industrial processes, such as the hydroformylation of long chain alkenes. ${ }^{44 c]}$

A few common organic solvents (such as 2-propanol) may also act as H-donors in transfer hydrogenations; in addition, they may influence the formation of catalytically important metal complex intermediates (such as metal hydrides). Nevertheless, there are reactions where such effects can hardly be relevant for the observed dramatic rate increase. For example, we have found that transfer hydrogenation of aldehydes from aqueous HCOONa catalysed by $\left[\left\{\mathrm{RuCl}_{2}(m \text { tppms })_{2}\right\}_{2}\right]$ (with added $m \mathrm{t}-$ ppms) was largely accelerated upon addition of 2-propanol as co-solvent; in case of trans-cinnamaldehyde $90 \%$ conversion was achieved in a water/2-propanol 2/1 mixture in contrast to $2.0 \%$ in water alone. ${ }^{[20]}$ In the homogeneous reaction mixtures of that study with no gaseous reactants, phase-transfer and solubility effects could not lead to the substantially increased reaction rates. In order to get a deeper insight into the causes of this kinetic phenomenon, we decided to study a similar yet different reaction, i.e. the transfer hydrogenation of aldehydes from aqueous HCOONa catalysed by $\left[\mathrm{RhCl}(m \text { tppms })_{3}\right]$. Since in the case of unsaturated aldehydes this catalyst shows markedly different selectivity than $\left[\left\{\mathrm{RuCl}_{2}(m \mathrm{tppms})_{2}\right\}_{2}\right]+n m$ tppms, transfer hydrogenation of trans-cinnamaldehyde was investigated in detail; the results are reported below.

\section{Results}

Hydrogenation of trans-cinnamaldehyde (Scheme 1; A) may yield three products, namely 3-phenylpropanal (B), cinnamyl alcohol (3-phenyl-2-propenol, C), and 3-phenylpropanol (D). In general, unsaturated alcohols are regarded more valuable due to their role in synthesis especially in the fragrance industry.

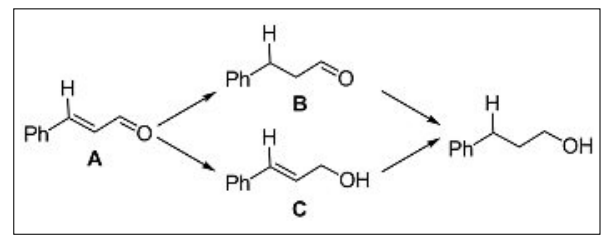

Scheme 1. Hydrogenation of trans-

cinnamaldehyde (trans-3-phenyl-2-propenal).

Earlier we reported that $\left[\mathrm{RhCl}(m \mathrm{tppms})_{3}\right]$ was a poor catalyst for transfer hydrogenation of aldehydes below $50{ }^{\circ} \mathrm{C}$ in a $5 \mathrm{M}$ aqueous $\mathrm{HCOONa}$ chlorobenzene biphasic system. ${ }^{[14 a, 17]}$ Similarly, only $\leq 6 \%$ conversions were obtained in this study using water alone as solvent. However, we have found that in mixtures of water and 2-propanol transfer hydrogenation of trans-cinnamaldehyde from formate proceeded smoothly already at $30{ }^{\circ} \mathrm{C}$ (Fig. 1), and yielded 3-phenylpropanal exclusively. (Under the same conditions but at $50{ }^{\circ} \mathrm{C} 3$-phenylpropanal was reduced slowly with a conversion of $11.9 \%$ in $1 \mathrm{~h}$.) When the final reaction mixture was treated with toluene $(3 \mathrm{ml})$ the toluene-rich phase was colourless and the catalyst could be recovered in the aqueous phase which showed the characteristic orange colour of the $\mathrm{Rh}(\mathrm{I})-m$ tppms complex(es).

The time course of the reaction showed that at longer reaction times close to quantitative conversion of trans-cinnamaldehyde to 3-phenylpropanal could be achieved. However, in most cases we followed the reaction for $1 \mathrm{~h}$ during which the conversion increased steadily with time and in most cases the conversions reached in the first hour of the reactions were used to characterize the reaction rate.

Other water-miscible organic solvents showed similar rate-increasing effects (Table 1). With the exception of glycerol the conversions achieved in $1 \mathrm{~h}$ at $30{ }^{\circ} \mathrm{C}$ fell in the range of $40.6-49.8 \%$. The solvent effect was investigated in detail using 2-propanol, due to its easy availability in high purity and to its relatively high boiling 


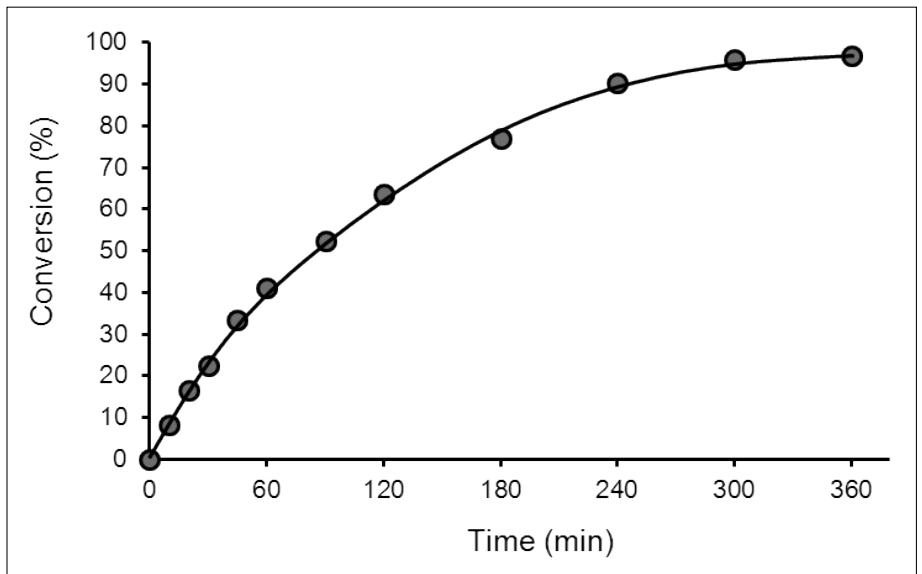

Fig. 1. Time course of the transfer hydrogenation of cinnamaldehyde catalysed by $\left[\mathrm{RhCl}\left(m \mathrm{tppms}_{3}\right]\right.$. Conditions as in Table 1. two-sided (Fig. 4). At low aldehyde concentrations the conversion increased with increased substrate concentrations, while it showed decreasing values with $[\mathrm{S}] /[\mathrm{Rh}]$ ratios higher than 50. However, the TOF vs $[\mathrm{S}] /[\mathrm{Rh}]$ function is a conventional saturation curve with slight decrease of TOF values toward high substrate concentrations. Although substrate inhibition in transfer hydrogenation of aldehydes is a known phenomenon, ${ }^{[13,20]}$ in this case it does not play an important role.

The hydrogenation activity of Wilkinson-type rhodium(I) complexes is often inhibited by additional phosphine ligands, point. With this co-solvent, under the conditions of Table 1, the turnover frequency of the catalyst for the first hour was $41 \mathrm{~h}^{-1}$ $(\mathrm{TOF}=$ mol reacted aldehyde $\times(\mathrm{mol}$ catalyst $\left.)^{-1} \times \mathrm{h}^{-1}\right)$.

Table 1. Effect of organic co-solvents on transfer hydrogenation of trans-cinnamaldehyde with $\left[\mathrm{RhCl}(\mathrm{mtppms})_{3}\right]$ catalyst.

\begin{tabular}{|l|l|}
\hline Co-solvent & Conversion [\%] \\
\hline methanol & 46.3 \\
\hline ethanol & 40.6 \\
\hline 2-propanol & 41.0 \\
\hline acetone & 49.8 \\
\hline 2-ethoxyethanol & 49.6 \\
\hline glycerol & 23.3 \\
\hline
\end{tabular}

Conditions: $4.0 \mathrm{ml}$ water; $3.5 \mathrm{ml}$ organic solvent; $6 \mathrm{mmol} \mathrm{HCOONa} ; 1 \mathrm{mmol}$ trans-cinnamaldehyde; $0.01 \mathrm{mmol}\left[\mathrm{RhCl}(m \mathrm{tppms})_{3}\right] ; 0.07 \mathrm{mmol}$ mtppms; $\mathrm{T}=30^{\circ} \mathrm{C} ; \mathrm{t}=1 \mathrm{~h}$.

The conversion of trans-cinnamaldehyde varied characteristically with solvent composition and showed a maximum (plateau) between 25 and 70\%v/v 2-propanol concentration (Fig. 2). It should be added that in this concentration range the reaction mixtures were homogeneous, however, below 20\%v/v 2-propanol content the substrate trans-cinnamaldehyde, while with more than $80 \% \mathrm{v} / \mathrm{v} 2$-propanol the hydrogen donor HCOONa did not dissolve completely in the solvent mixture. For further investigations we choose a solvent mixture of $4.0 \mathrm{ml}$ water and $3.5 \mathrm{ml}(46.6 \% \mathrm{v} / \mathrm{v})$ 2-propanol.

The conversion of trans-cinnamaldehyde after $1 \mathrm{~h}$ as a function of the HCOONa concentration is shown in Fig. 3. Interestingly, even with a relatively high formate excess (10 mmol $\mathrm{HCOONa} / 1$ mmol aldehyde) the conversion was only $52 \%$ in contrast to the $22 \%$ observed with $2 \mathrm{mmol}$ Na-formate.

The effect of the [substrate]/[catalyst] $([\mathrm{S}] /[\mathrm{Rh}])$ ratio on the conversion is

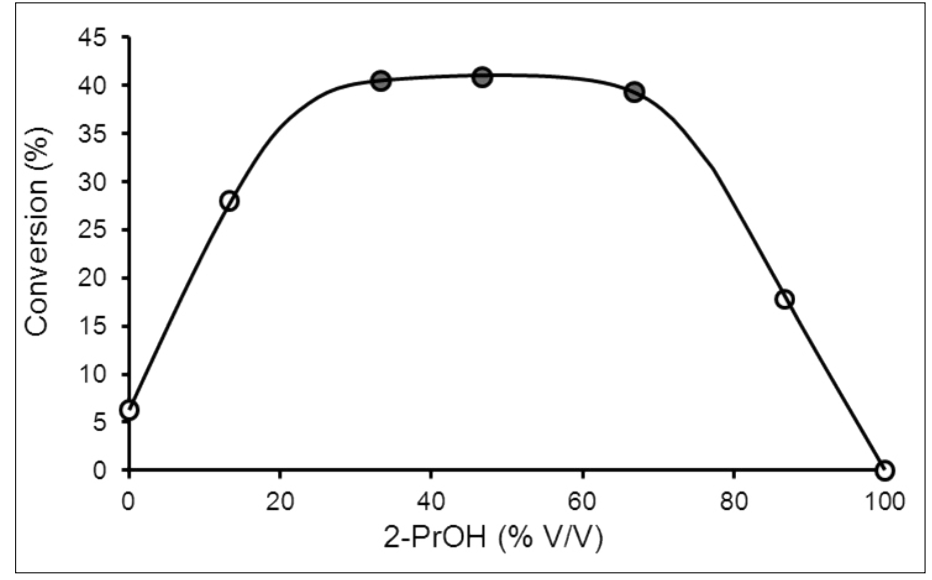

Fig. 2. Effect of solvent composition on the transfer hydrogenation of cinnamaldehyde catalysed by [RhCl(mtppms) $)_{3}$. Conditions as in Table 1.

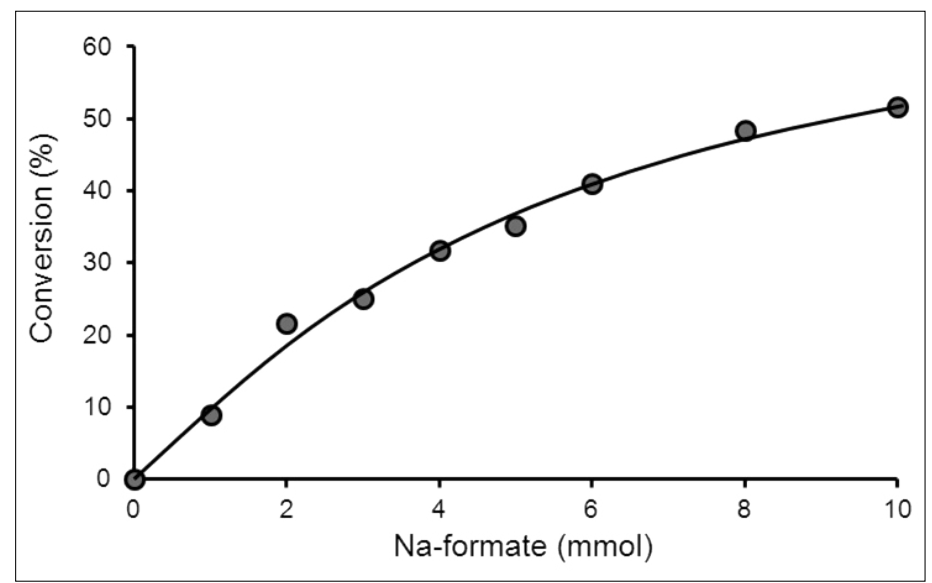

Fig. 3. Transfer hydrogenation of cinnamaldehyde catalysed by $\left[\mathrm{RhCl}(m \mathrm{tppms})_{3}\right]$ as a function of $\mathrm{H}$-donor (formate) concentration. Conditions as in Table 1.

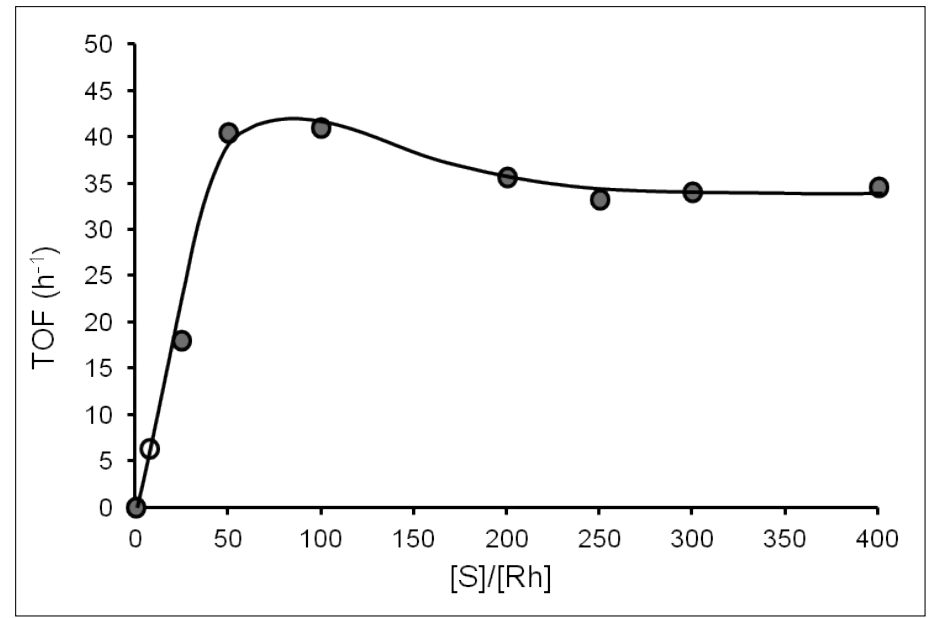

Fig. 4. Transfer hydrogenation of cinnamaldehyde [substrate]/[Rh] ratio. Conditions as in Table 1. as a function of the 
therefore this effect was also investigated. As shown on Fig. 5, the conversion of trans-cinnamaldehyde in transfer hydrogenation from aqueous formate increased up to a $[\mathrm{P}]_{\mathrm{T}} /[\mathrm{Rh}]$ ratio of 5 , then levelled off $\left([\mathrm{P}]_{\mathrm{T}}\right.$ includes the three $m$ tppms ligands, too, bound in $\left.\left[\mathrm{RhCl}(m \mathrm{tppms})_{3}\right]\right)$. This was the reason we used $[\mathrm{P}]_{\mathrm{T}} /[\mathrm{Rh}]=10$ in all other experiments.

The reaction rate showed a large temperature dependence (Fig. 6). Under the conditions of Table 1, a TOF of $41 \mathrm{~h}^{-1}$ was determined at $30{ }^{\circ} \mathrm{C}$, which increased to $276 \mathrm{~h}^{-1}$ at $50{ }^{\circ} \mathrm{C}$ and to $1214 \mathrm{~h}^{-1}$ at $70{ }^{\circ} \mathrm{C}$. This latter value is unprecedently high for transfer hydrogenation of trans-cinnamaldehyde from aqueous formate with a water-soluble Rh(I)-tertiary phosphine catalyst. For comparison, in the biphasic hydrogenation of trans-cinnamaldehyde catalysed by $\left[\mathrm{RhCl}(m \text { tppts })_{3}\right]$ a $\mathrm{TOF}=267$ $\mathrm{h}^{-1}$ was determined at $80{ }^{\circ} \mathrm{C}$ and 20 bar $\mathrm{H}_{2} \cdot$ [15a]

A good linearity Arrhenius plot of ln TOF vs. 1/T $\left(\mathrm{R}^{2}=0.9954\right)$ yielded an apparent activation energy $\mathrm{E}_{\mathrm{a}}=89 \mathrm{~kJ} / \mathrm{mol}$.

The high catalytic activity in the transfer hydrogenation of trans-cinnamaldehyde encouraged us to attempt an industrially important reaction, namely the selective hydrogenation of citral (3,7-dimethyl-oct-6-en-1-al, a mixture of cis- and trans-isomers: geranial and neral). The results are shown in Table 2. The major products of the reaction were geraniol and nerol which are obtained by hydrogenation of the aldehyde function of geranial and neral, respectively. At $30{ }^{\circ} \mathrm{C}$ the reaction was fairly selective to geraniol (76\% of all products), however, at higher temperatures its ratio among the products decreased to about $50 \%$.

Selective hydrogenation of the conjugated $\mathrm{C}=\mathrm{C}$ bond in citral yielding citronellal amounted to $15.1 \%$ at $70{ }^{\circ} \mathrm{C}$ (the isolated $\mathrm{C}=\mathrm{C}$ bond was not hydrogenated at any of the studied temperatures). This $\mathrm{C}=\mathrm{C} / \mathrm{C}=\mathrm{O}$ selectivity is different from that observed in hydrogenation of trans-cinnamaldehyde and may be the consequence of the higher degree of substitution of both olefinic bonds in citral.

\section{Discussion}

In this study we observed that reduction of trans-cinnamaldehyde by catalytic hydrogen transfer from HCOONa with the water-soluble $\left[\mathrm{RhCl}(m \text { tppms })_{3}\right]$ catalyst proceeded much faster in water/2-propanol mixtures than in water as the sole solvent and consequently the reaction could be run with high conversion already at $30{ }^{\circ} \mathrm{C}$.

In search for the probable catalytically active $\mathrm{Rh}$-species we studied the reaction of $\left[\mathrm{RhCl}(m \text { tppms })_{3}\right]$ with HCOONa in wa-

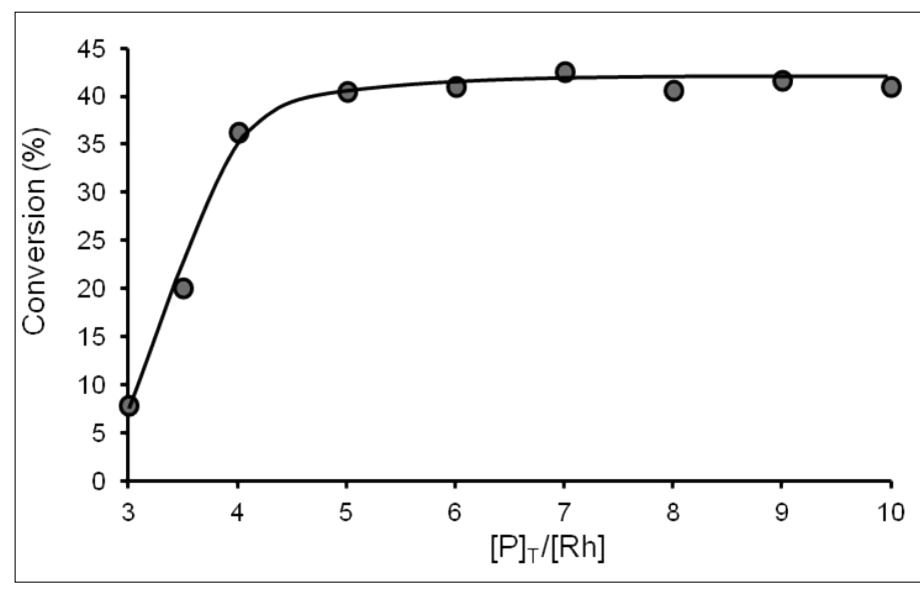

Fig. 5. Transfer hydrogenation of cinnamaldehyde as a function of the $[\mathrm{P}]_{\mathrm{T}} /$ [Rh] ratio. Conditions as in Table 1.

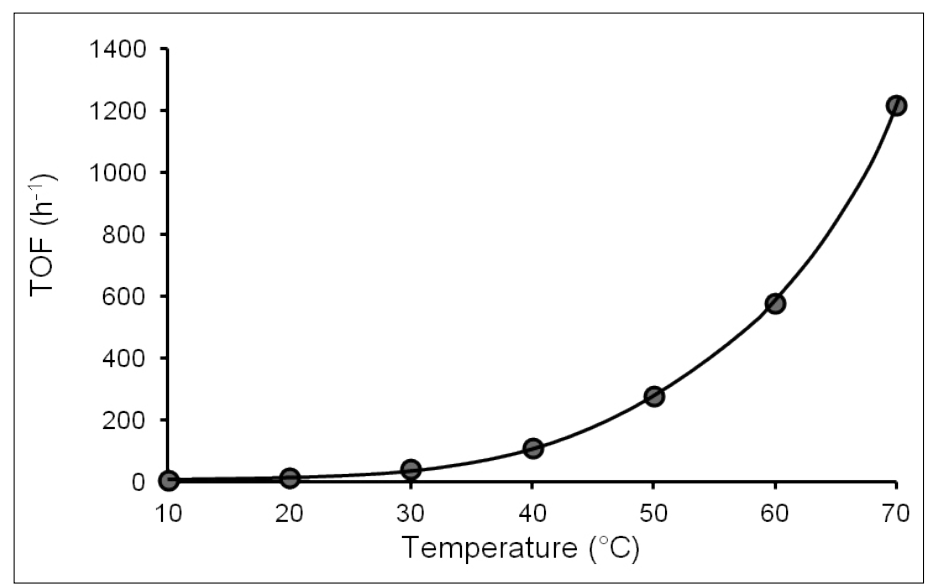

Fig. 6. Transfer hydrogenation of cinnamaldehyde as a function of the temperature. Conditions as in Table 1.

Table 2. Hydrogenation of citral by hydrogen transfer from formate in a mixture of water and 2-propanol catalysed by $\left[\mathrm{RhCl}\left(m \mathrm{tppms}_{3}\right]\right.$.

\begin{tabular}{|l|l|l|l|l|l|}
\hline $\begin{array}{l}\text { T } \\
{\left[{ }^{\circ} \mathrm{C}\right]}\end{array}$ & $\begin{array}{l}\text { Conversion } \\
{[\%]}\end{array}$ & $\begin{array}{l}\text { Citronellal } \\
{[\%]}\end{array}$ & $\begin{array}{l}\text { Citronellol } \\
{[\%]}\end{array}$ & $\begin{array}{l}\text { Nerol } \\
{[\%]}\end{array}$ & $\begin{array}{l}\text { Geraniol } \\
{[\%]}\end{array}$ \\
\hline 30 & 22.4 & 0 & 2.2 & 3.2 & 17.0 \\
\hline 40 & 59.0 & 3.1 & 7.2 & 8.9 & 39.8 \\
\hline 50 & 82.7 & 9.6 & 12.0 & 13.6 & 47.5 \\
\hline 60 & 92.7 & 14.6 & 15.8 & 16.7 & 45.6 \\
\hline 70 & 94.2 & 15.1 & 16.2 & 19.4 & 43.5 \\
\hline
\end{tabular}

Conditions: $1 \mathrm{mmol}$ citral; $6 \mathrm{mmol} \mathrm{HCOONa} ; 0.01 \mathrm{mmol}\left[\mathrm{RhCl}(m \mathrm{tppms})_{3}\right] ; 0.07 \mathrm{mmol} m \mathrm{tppms} ; 4$ $\mathrm{ml}$ water; $3.5 \mathrm{ml}$ 2-propanol; $\mathrm{t}=1 \mathrm{~h}$.

ter/2-propanol $=4.0 / 3.5 \mathrm{v} / \mathrm{v}$ mixtures using ${ }^{1} \mathrm{H}$ - and ${ }^{31} \mathrm{P}-\mathrm{NMR}$ spectroscopies. With standard decoupling techniques it was established that in the first few minutes following dissolution of $\left[\mathrm{RhCl}(m \mathrm{tppms})_{3}\right]$ the solutions contained cis-mer- $\left[\mathrm{H}_{2} \mathrm{Rh}(\mathrm{H}-\right.$ $\left.\mathrm{COO})(m \mathrm{tppms})_{3}\right]$, however signals of cis$m e r-\left[\mathrm{H}_{2} \mathrm{Rh}\left(\mathrm{H}_{2} \mathrm{O}\right)(m \text { tppms })_{3}\right]^{+} \quad$ appeared almost simultaneously (Fig. 7) and their intensity increased in time at the expense of those of the formato complex. In separate gas volumetric experiments it was determined that in such water/2-propanol mixtures $\left[\mathrm{RhCl}(m \text { tppms })_{3}\right]$ catalysed the decomposition of aqueous formate to $\mathrm{H}_{2}$ and bicarbonate with a turnover frequen- cy of $70 \mathrm{~h}^{-1}$ at $30{ }^{\circ} \mathrm{C}$. A plausible path of formation of the hydrido complexes is the initial replacement of $\mathrm{Cl}^{-}$by $\mathrm{HCOO}^{-}$, followed by either nucleophilic attack of $\mathrm{OH}^{-}$on the formato carbon atom and subsequent rearrangement or by oxidative addition of $\mathrm{H}_{2}$ produced by catalytic decomposition of $\mathrm{HCOO}^{-}$. In acidic solutions, in the presence of additional chloride, formation of cis-mer- $\left[\mathrm{H}_{2} \mathrm{RhCl}(m \text { tppts })_{3}\right]$ from hydrated $\mathrm{RhCl}_{3}$ and $m$ tppts under $\mathrm{H}_{2}$ was observed by Larpent and Patin, ${ }^{[21]}$ while under similar conditions we detected the presence of cis-mer- $\left[\mathrm{H}_{2} \mathrm{RhCl}(m \mathrm{tppms})_{3}\right]$ in solutions of $\left[\mathrm{RhCl}(m \mathrm{tppms})_{3}\right]$ and $\mathrm{H}_{2} \cdot{ }^{[10 \mathrm{~b}]}$ In both studies, ${ }^{[10 b, 21]}$ formation of $c i s-f a c$ - 
$\left[\mathrm{H}_{2} \mathrm{RhXP}_{3}\right]\left(\mathrm{X}=\mathrm{Cl}^{-}\right.$or $\mathrm{H}_{2} \mathrm{O} ; \mathrm{P}=m$ tppts or $m$ tppms) was also revealed by ${ }^{1} \mathrm{H}$ - and ${ }^{31} \mathrm{P}-\mathrm{NMR}$ spectroscopies.

Since HCOONa can also act as a mild base, and in the presence of bases 2-propanol is known to act as $\mathrm{H}$-donor the question arises whether in our systems it behaves only as an inert solvent or whether it takes part in the hydrogen transfer reaction of aldehydes. To answer this question we attempted transfer hydrogenation of trans-cinnamaldehyde under our standard conditions, however, $\mathrm{Na}$-formate was replaced by $\mathrm{Na}_{2} \mathrm{CO}_{3}$ or $\mathrm{NaHCO}_{3}$ (the latter compound accumulates in the reaction mixture during transfer hydrogenation or as a product of concomitant decomposition of formate). At $30{ }^{\circ} \mathrm{C}$ in 4 hours the conversion of trans-cinnamaldehyde was less than $1 \%$ with $\mathrm{Na}_{2} \mathrm{CO}_{3}$ while no conversion at all was detected with $\mathrm{NaHCO}_{3}$ as base. Accordingly, it can be concluded that in the above transfer hydrogenation experiments 2-propanol did not serve as an $\mathrm{H}$-donor. On the basis of these findings and of the kinetic features of the reaction a possible catalytic cycle is shown on Scheme 2.
According to this suggestion, trans-cinnamaldehyde coordinates through its $\mathrm{C}=\mathrm{C}$ bond replacing the aqua ligand in cis$m e r-\left[\mathrm{H}_{2} \mathrm{Rh}\left(\mathrm{H}_{2} \mathrm{O}\right)(m \text { tppms })_{3}\right]^{+}$. Reductive elimination of 3-phenylpropanal and coordination of $\mathrm{HCOO}^{-}$yields $[\mathrm{Rh}(\mathrm{HCOO})$ (mtppms) $)_{3}$ which regenerates cis-mer$\left[\mathrm{H}_{2} \mathrm{Rh}\left(\mathrm{H}_{2} \mathrm{O}\right)(m \text { tppms })_{3}\right]^{+}$in internal redox reactions. While several small details of this mechanism are still to be discovered, this suggestion is in accordance with the presence of cis-mer- $\left[\mathrm{H}_{2} \mathrm{Rh}(\mathrm{HCOO})(m \mathrm{t}-\right.$ ppms $\left.)_{3}\right]$ and cis-mer- $\left[\mathrm{H}_{2} \mathrm{Rh}\left(\mathrm{H}_{2} \mathrm{O}\right)(m\right.$ tppms) $\left.{ }_{3}\right]^{+}$as shown by the NMR investigations and accounts for the observed kinetic phenomena, such as the increase of reaction rate with increasing formate concentration (Fig. 3) and the lack of phosphine inhibition (Fig. 5).

Although the $\left[\mathrm{RhCl}(m \text { tppms })_{3}\right]-$ catalysed transfer hydrogenation of trans-cinnamaldehyde proved fairly selective towards formation of the saturated aldehyde 3-phenylpropanal, at longer reaction times or at higher temperatures substantial amounts of the saturated alcohol, 3-phenylpropanol were obtained.

$\begin{array}{|rll|} & \\ & & \\ & & \\ & & \\ \delta \mathrm{P}^{(\mathrm{a})} / \mathrm{ppm} & 40.88(\mathrm{~m}) & 38.85(\mathrm{~m}) \\ \delta \mathrm{P}^{(\mathrm{b})} / \mathrm{ppm} & 22.87(\mathrm{~m}) & 21.32(\mathrm{~m}) \\ \delta \mathrm{H}^{(\mathrm{x})} / \mathrm{ppm} & -9.97 & -9.81 \\ \delta \mathrm{H}^{(\mathrm{y})} / \mathrm{ppm} & -19.69 & -17.78 \\ \delta \mathrm{C}^{(\mathrm{HCOO}-)} / \mathrm{ppm} & 173.8(\mathrm{~m}) & \\ J \mathrm{P}^{(\mathrm{a})} \mathrm{H}^{(\mathrm{x}, \mathrm{y})} / \mathrm{Hz} & 14 & 12 \\ J \mathrm{P}^{(\mathrm{b})} \mathrm{H}^{(\mathrm{x}, \mathrm{y})} / \mathrm{Hz} & 151.0 & 152.6 \\ J \mathrm{P}^{(\mathrm{a})} \mathrm{P}^{(\mathrm{b})} / \mathrm{Hz} & 19.2 & 18.4 \\ J \mathrm{P}^{(\mathrm{a})} \mathrm{Rh} / \mathrm{Hz} & 92.0 & 91.0 \\ J \mathrm{P}^{(\mathrm{b})} \mathrm{Rh} / \mathrm{Hz} & 114.7 & 114.4 \\ J \mathrm{H}^{(\mathrm{x})} \mathrm{H}^{(\mathrm{y})} / \mathrm{Hz} & \sim 10 & \sim 10 \\ & & \end{array}$

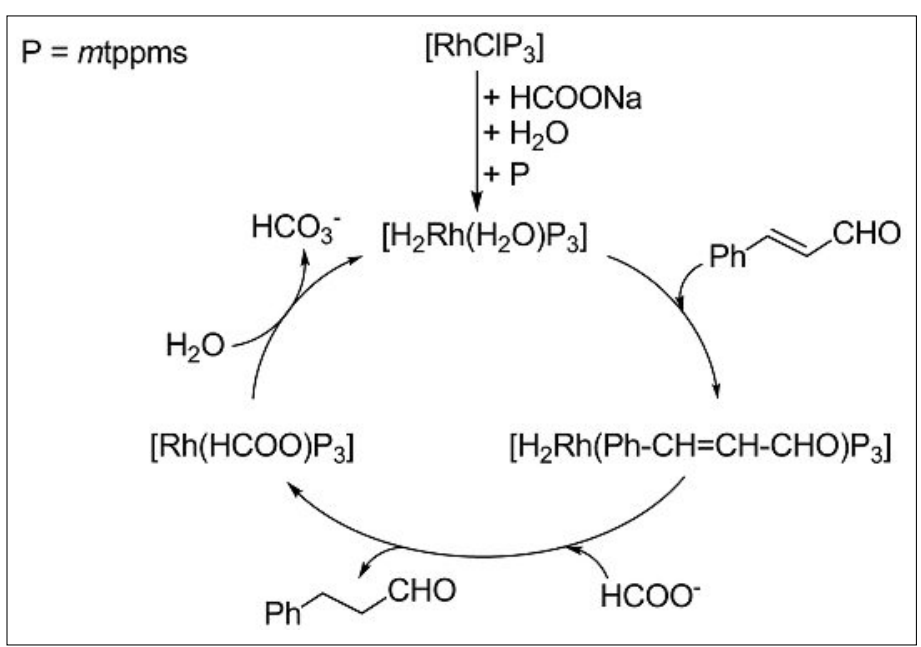

Accordingly, 3-phenylpropanal was reduced to 3-phenylpropanol, albeit slowly, at $50{ }^{\circ} \mathrm{C}(11.9 \%$ conversion in $1 \mathrm{~h})$. Other saturated aldehydes were also hydrogenated with this Rh-based catalyst by hydrogen transfer from formate. For example, under our standard conditions benzaldehyde was reduced with $60.3 \%$ conversion (reaction time: $1 \mathrm{~h}$ ). We suggest that the reduction of the aldehyde function takes place with no prior coordination of the substrate to the metal and involves a hydride attack from cis-mer- $\left[\mathrm{H}_{2} \mathrm{RhX}(m \text { tppms })_{3}\right]\left(\mathrm{X}=\mathrm{HCOO}^{-}\right.$ or $\mathrm{H}_{2} \mathrm{O}$ ) on the carbonyl oxygen resulting in formation of a hydroxyalkyl-Rh intermediate. Protonation of this intermediate and further redox reaction with formate would regenerate cis-mer- $\left[\mathrm{H}_{2} \mathrm{RhX}(m \mathrm{tp}-\right.$ pms) $)_{3}$. This suggestion is similar to that put forward by Basset et al. to explain the large rate-increasing effect of various cations on the hydrogenation of propanal with $\mathrm{Ru}(\mathrm{II})-m$ tppts catalysts. ${ }^{[22]}$

Concerning the origin of the rate-increasing effect of 2-propanol the biggest part probably comes from the dissolution of aldehydes into the aqueous phase. Solubility of trans-cinnamaldehyde in water at $30{ }^{\circ} \mathrm{C}$ is $1.42 \mathrm{mg} / \mathrm{ml}^{[23]}$ and accordingly $0.0805 \mathrm{mmol}$ of this compound is dissolved in $7.5 \mathrm{ml}$ aqueous reaction medium. In the homogeneous solution of $1 \mathrm{mmol}$ trans-cinnamaldehyde obtained with $4.0 \mathrm{ml}$ water $+3.5 \mathrm{ml}$ 2-propanol the aldehyde concentration is 12.4 times higher than in water alone. Nevertheless, this concentration gives an $[\mathrm{S}] /[\mathrm{C}]$ value of 100 which already implies the saturation value of TOF (see Fig. 4). It should also be mentioned that although the reaction mixtures were homogeneous already at $20 \% \mathrm{v} / \mathrm{v} 2$-propanol concentration, the conversion of trans-cinnamaldehyde significantly increased further with increasing 2-propanol/water ratio (from $28 \%$ to $41 \%$, see Fig. 2) and varied according to a maximum curve (with a plateau between 25 and $70 \mathrm{v} / \mathrm{v}$ propanol concentrations). It is of interest that changes in the solvent composition did not change the selectivity of the reaction; at $30{ }^{\circ} \mathrm{C} 3$-phenylpropanal was obtained exclusively. Although we did not attempt repeated use of the same catalyst, we demonstrated that it could be recovered in the aqueous phase after the product and unreacted cinnamaldehyde were extracted from the water/2-propanol reaction mixtures with toluene. ${ }^{[24]}$

In comparison to the effect of 2-propanol on the rate of transfer hydrogenation of trans-cinnamaldehyde from aqueous formate catalysed by $\mathrm{Ru}(\mathrm{II})-m$ tppms complexes (a 45-fold acceleration), the rate increase in the case of the $\left[\mathrm{RhCl}(m \mathrm{tppms})_{3}\right]-$ catalysed reaction is smaller $(6.5 \times)$, and can be largely, although not completely ascribed to the dissolution of the substrate 
into the aqueous reaction mixture. It is tempting to speculate that part of the effect originates from changes in the water/2-propanol solvent structure with changing composition. For example, the viscosity of water/2-propanol mixtures changes markedly and shows a pronounced maximum at $61 \%$ v/v 2-propanol concentration due to the rearrangement of the intra- and intermolecular H-bond network ${ }^{[25]}$ and propanol may substantially effect the aldehyde-water $\mathrm{H}$-bonding interactions. However, since sufficient information is not available, at this stage the possible connection between such solvent structural changes and the kinetics of the transfer hydrogenation of trans-cinnamaldehyde remains elusive.

\section{Experimental}

\subsection{Reagents and Methods}

Aldehydes (Aldrich) and other reagents and solvents were commercially available and used as received; $m$ tppms ${ }^{[6]}$ and $\left[\mathrm{RhCl}(m \text { tppms })_{3}\right]^{[6]}$ were prepared by published procedures.

All reactions and manipulations were carried out under argon atmosphere. Reaction mixtures were analysed by gas chromatography (HP5890 Series II; Chrompack WCOT Fused Silica 30m*32mm CP WAX52CB; FID; carrier gas: argon). The products were identified by comparison of their retention times to those of known compounds. ${ }^{1} \mathrm{H},{ }^{13} \mathrm{C}$ and ${ }^{31} \mathrm{P}$ NMR spectra were recorded on a Bruker Avance $360 \mathrm{MHz}$ spectrometer and referenced to tetramethylsilane (TMS), sodium 2,2-dimethyl-2-silapentane-5-sulfonate (DSS) or to external $85 \% \mathrm{H}_{3} \mathrm{PO}_{4}$.

\subsection{Catalytic Transfer Hydrogenation of Cinnamaldehyde}

In a typical reaction $408 \mathrm{mg}(6 \mathrm{mmol})$ sodium formate and $126 \mu \mathrm{l}(1 \mathrm{mmol})$ cinnamaldehyde were added to a mixture of $4.0 \mathrm{ml}$ water and $3.5 \mathrm{ml} \mathrm{2-pro-}$ panol at $\mathrm{T}=30{ }^{\circ} \mathrm{C} .13 \mathrm{mg}(0.01 \mathrm{mmol})$ $\left[\mathrm{RhCl}(m \text { tppms })_{3}\right]$ and $28 \mathrm{mg}(0.07 \mathrm{mmol})$ $m$ tppms were dissolved in the deoxygenated solution and the mixture was stirred vigorously. Samples $(0.2 \mathrm{ml})$ were withdrawn periodically (or taken at a pre-set reaction time), diluted with $1 \mathrm{ml}$ of water and extracted by toluene. The organic extract was filtered through a short silica plug and analysed by gas chromatography.

\section{Acknowledgements}

The research was supported by the EU and co-financed by the European Social Fund under the project ENVIKUT (TÁMOP-4.2.2.A-11/1/ KONV-2012-0043). Thanks are due to the Hungarian Research Fund (OTKA K101372) for financial support. G. P. is grateful for a János Bolyai Research Scholarship of the Hungarian Academy of Sciences.

Received: April 24, 2015

[1] 'Handbook of Homogeneous Hydrogenation', Eds J. G. de Vries, C.J. Elsevier,Wiley-VCH, Weinheim, 2007.

[2] 'Handbook of Metathesis', Ed. R. H. Grubbs, Wiley-VCH, Weinheim, 2003.

[3] a) D. J. Adams, P. J. Dyson, S. J. Tavener, 'Chemistry in Alternative Reaction Media' Wiley, Chichester, 2004; b) 'Multiphase Homogeneous Catalysis', Eds B. Cornils, W. A. Herrmann, I. T. Horváth, W. Leitner, S. Mecking, H. Olivier-Bourbigou, D. Vogt, Wiley-VCH, Weinheim, Germany, 2005.

[4] a) F. Joó, 'Aqueous Organometallic Catalysis', Kluwer, Dordrecht, 2001; b) 'Aqueous-Phase Organometallic Catalysis', Eds B. Cornils, W. A. Herrmann, 2nd ed., Wiley-VCH, Weinheim, 2004; c) F. Joó, Á. Kathó in 'Handbook of Green Chemistry: Reactions in Water', Ed. C.-J. Li, Wiley-VCH, Weinheim, 2010, p. 389; d) F. Joó, Á. Kathó, in 'Handbook of Homogeneous Hydrogenation', Eds. J.G. de Vries, C. J. Elsevier, Wiley-VCH, Weinheim, 2007, vol. 3, ch. 38, p. 1327; e) 'Metal-catalyzed Reactions in Water', Eds P. Dixneuf, V. Cadierno, WileyVCH, Weinheim, 2013; f) F. Joó, Acc. Chem. Res. 2002, 35, 738 .

[5] a) A. Almássy, C. E. Nagy, A. C. Bényei, F. Joó, Organometallics 2010, 29, 2484; b) C. E. Czégéni, G. Papp, Á. Kathó, F. Joó, J. Mol. Catal. A: Chem. 2011, 340, 1; c) V. Cadierno, J. Francos, J. Gimeno, Chem. Eur. $J$. 2008, 14, 6601; d) R. Garcia-Álvarez, P. Crochet, V. Cadierno, Green Chem. 2013, 15, 46; e) R. García-Álvarez, J. Francos, E. Tomás-Mendivil, P. Crochet, V. Cadierno, J. Organomet. Chem. 2014, 771, 93; f) W-C Lee, B. J. Frost, Green Chem. 2012, 14, 62; g) E. Bolyog-Nagy, A. Udvardy, F. Joó, Á. Kathó, Tetr. Lett. 2014, 55, 3615.

[6] F. Joó, J. Kovács, Á. Kathó, A. Cs. Bényei, T. Decuir, D.J. Darensbourg, Inorg. Synth. 1998, $32,1$.

[7] W. A. Herrmann, C. W. Kohlpaintner, Inorg. Synth. 1998, 32, 8.

[8] D. J. Daigle, Inorg. Synth. 1998, 32, 40.

[9] a) M. Fekete, F. Joó, Catal. Commun. 2006, 10,783 ; b) H. D. Velazquez, F. Verpoort, Chem. Soc. Rev. 2012, 41, 7032; c) D. Jantke, M. Cokoja, A. Pöthig, W. A. Herrmann, F. E. Kühn, Organometallics 2013, 32, 741; d) L.
A. Schaper, S. J. Hock, W. A. Herrmann, F. E. Kühn, Angew. Chem. Int. Ed. 2013, 52, 270; e) H. Horváth, Á. Kathó, A. Udvardy, G. Papp, D. Szikszai, F. Joó, Organometallics 2014, 33, 6330.

[10] a) F. Joó, L. Somsák, M.T. Beck, J. Mol. Catal. 1984, 24, 7; b) F. Joó, J. Kovács, A. Cs. Bényei, L. Nádasdi, G. Laurenczy, Chem. Eur. J. 1999 , 5,$1544 ;$ c) F. Joó, P. Csiba, A. Bényei, J. Chem. Soc. Chem. Commun. 1993, 1602.

[11] A. Udvardy, Á. Kathó, React. Kin. Catal. Lett. 2008, 95,81 .

[12] a) X. Wu, X. Li, W. Hems, F. King, J. Xiao, Org. Biomol. Chem. 2004, 2, 1818; b) X. Wu, J. Xiao, Chem. Commun. 2007, 2449; c) X. Wu, J. Liu, D. Di Tommaso, J. A. Iggo, C. R. A. Catlow, J. Bacsa, J. Xiao, Chem. Eur. J. 2008, 14, 7699; d) S. Liu, J. Xiao, in 'Bridging Heterogeneous and Homogeneous Catalysis: Concepts, Strategies, and Applications', Eds. C. Li, Y. Liu, Wiley$\mathrm{VCH}$, Weinheim, 2014, p. 201.

[13] a) R. Bar, Y. Sasson, J. Blum, J. Mol. Catal. 1984, 26, 327; b) R. Bar, L. K. Bar, Y. Sasson, J. Blum, J. Mol. Catal. 1985, 33, 161.

[14] a) F. Joó, A. Bényei, J. Organomet. Chem. 1989, 363, C19; b) D. J. Darensbourg, F. Joó, M. Kannisto, Á. Kathó, J. H. Reibenspies, Organometallics 1992, 11, 1990; c) D. J. Darensbourg, F. Joó, M. Kannisto, Á. Kathó, J. H. Reibenspies, D. J. Daigle, Inorg. Chem. 1994, 33, 200 d) D. Carmona, F. J. Lahoz, R. Atencio, L. A. Oro, M. Pilar Lamata, F. Viguri, E. San José, C. Vega, J. Reyes, F. Joó, Á. Kathó, Chem. Eur. J. 1999, 5, 1544.

[15] a) J. M. Grosselin, C. Mercier, G. Allmang, F. Grass, Organometallics 1991, 10, 2126; b) K. Nuithitikul, M. Winterbottom, Chem. Eng. Sci. 2004, 59, 5439; c) K. Nuithitikul, M. Winterbottom, Catal. Today 2007, 128, 74; d) L. G. Melean, M. Rodriguez, A. Gonzalez, B. Gonzalez, M. Rosales, P.J. Baricelli, Catal. Lett. 2011, 141, 709.

[16] a) F. Joó, J. Kovács, A. C. Bényei, Á. Kathó, Angew. Chem. 1998, 110, 1024; Angew. Chem. Int. Ed. Engl. 1998, 37, 969; b) F. Joó, J. Kovács, A. Cs. Bényei, Á. Kathó, Catal. Today 1998, 42, 441.

[17] A. Bényei, F. Joó, J. Mol. Catal. 1990, 58, 151.

[18] S. Di Dio, M. Marchetti, S. Paganelli, O. Piccolo, Appl. Catal. A: Gen. 2011, 399, 205.

[19] A. N. Ajjou, J.-L.Pinet, J. Mol. Catal. A: Chem. 2004, 214, 203

[20] I. Szatmári, G. Papp, Á. Kathó, F. Joó, Catal. Today 2015, 247, 14

[21] C. Larpent, H. Patin, J. Organomet. Chem. 1987, 335, C13.

[22] a) E. Fache, F. Senocq, C. Santini, J.-M. Basset, J. Chem. Soc., Chem. Commun. 1990, 1776; b) E. Fache, F. Senocq, C. Santini, J. M. Basset, J. Mol. Catal. 1992, 72, 337.

[23] S. C. Valvani, S. H. Yalkowsky, T. J. Roseman, J. Pharm. Sci. 1981, 70, 502.

[24] E. R. Washburn, A. E. Beguin, J. Am. Chem. Soc. 1940, 62, 579 .

[25] a) Y. Nagasawa, Y. Nakagawa, A. Nagafuji, T. Okada, H. Miyasaka, J. Mol. Struct. 2005, 735 , 217; b) T. T. Ngo, T. L. Yu, H. L. Lin, J. Power Sources 2013, 225, 293. 